\title{
Paradigma Lerner versus Konstruksi Gender
}

\author{
Mien Hidayat \\ ABSTRACT \\ Asumsi dasar Paradigma Lerner (dalam komunikasi pembangunan) menyatakan terbukanya \\ suatu wilayah dari isolasi fisik akan mendorong masyarakat berurbanisasi, yang selanjutnya \\ akan menghasilkan literasi. Kedua variabel ini akan memengaruhi partisipasi media massa. \\ Selanjutnya saling pengaruh dari ketiga variabel itu akan bermuara pada partisipasi \\ pembangunan Konstruksi gender yang berlangsung di masyarakat yang berlatar belakang \\ budaya patriarkhat ternyata mampu memandekkan aplikasi pemikiran Lerner, khususnya pada \\ ibu-ibu rumah tangga. Urbanisasi tidak berjalan karena gender mengonstruksikan ibu-ibu \\ rumah tangga untuk mendiami wilayah domestik. Gender juga menebar faham, pendidikan \\ lebih diprioritaskan untuk anak laki-laki ketimbang anak perempuan dengan alasan laki-laki \\ akan menjadi kepala rumah tangga yang bertanggung jawab terhadap keluarga. Terhambatnya \\ aplikasi kedua konsep ini cenderung memperkecil akses perempuan pada media massa, yang \\ pada akhirnya mengondisikan ibu-ibu rumah tangga (perempuan) dihimpit keterbatasan dalam \\ partisipasi pembangunan.
}

Kata kunci: paradigma lerner, konstruksi gender, partisipasi media.

\section{Pendahuluan}

Paradigma komunikasi pembangunan dari Lerner, telah menjadi klasik. Namun dalam aspek perubahan sosial yang terjadi di suatu daerah akibat terbukanya isolasi fisik melalui pembangunan jalan raya, paradigma tersebut masih tetap relevan. Dilatarbelakangi oleh berbagai hasil penelitian yang dilakukannya di berbagai negara di Timur Tengah dan Amerika Latin, Lerner merumuskan paradigma komunikasi pembangunan, yang merupakan pengembangan dari Aliran Modernisasi dari Model Proses (Abraham, 1991). Paradigmanya terdiri atas empat konsep utama yang saling berinteraksi, yaitu urbanisasi - literasi - terpaan media massa - dan partisipasi pembangunan.
Penelitian ini sekaligus akan menguji paradigma Lerner bila diterapkan pada ibu-ibu rumah tangga di pedesaan yang daerahnya baru terbuka dari isolasi teritorial, melalui variabelvariabel aktivitas mobilitas, kesempatan pendidikan, terpaan informasi, dan pengambilan keputusan dalam pemeliharaan kesehatan reproduksi.

Terdapat enam kecamatan di Provinsi Banten yang berada di wilayah Kabupaten Pandeglang bagian Selatan, yang pada 1978 baru terbebas dari keterasingan dengan dunia luar setelah selesai pembanguann jalan raya, yang dimulai 1976. Keterisolasian daerah tersebut sangat menghambat dinamika pembangunan karena sulitnya akses ke luar. Kesulitan akses keluar ini bukan hanya secara fisik, media massa pun sulit menembus daerah 
tersebut. Hanya radio yang mampu menembus hambatan geografis, namun kepemilikannya terbatas hanya pada sekelompok kecil elit desa. Begitupun dengan televisi selain relatif tidak terjangkau oleh daya beli masyarakat, juga daerah tersebut merupakan black spot, sehingga tidak dapat ditangkap baik. Media cetak lebih banyak lagi hambatan yang dihadapinya, selain daya beli masyarakat yang relatif rendah, pendistribusian menghadapi kendala transportasi, juga tingkat literasi masyarakat yang juga rendah.

Kondisi daerah Pandeglang Selatan itu, sesuai dengan pendapat Schoorl (1982) bahwa masyarakat tradisional yang bermukim di daerah yang terisolasi secara geografis, akan mengalami hambatan untuk berevolusi menuju masyarakat modern. Isolasi fisik menghambat penduduk untuk kontak dengan dunia luar. Padahal, kontak dengan dunia luarlah yang akan meningkatkan dinamika masyarakat secara sosial, ekonomi, dan budaya.

Penelitian ini akan mengkaji perbedaanperbedaan yang didasarkan pada empat pengelompokan ibu-ibu rumah tangga dengan karakterisktik yang saling berbeda pada ketiga daerah penelitian dengan sifat yang berbeda pula, dilihat dari aspek-aspek aktivitas mobilitas, kesempatan pendidikan yang diraih, terpaan informasi, dan pengambilan keputusan dalam pemeliharaan kesehatan reproduksi

\subsection{Permasalahan Wanita di Pedesaan}

Kurang dinamisnya kehidupan masyarakat akibat keterisolasian daerahnya, tentu saja melibatkan juga dinamika ibu-ibu rumah tangganya. Pada masyarakat yang tidak terisolasipun, cukup banyak masalah yang dihadapi wanita. Di tingkat internasional, The $4^{\text {th }}$ World Conference on Women, Beijing, 1995, menghasilkan 12 Isu keprihatinan Beijing. Empat di antaranya relevan dengan studi yang dilakukan:

- Keterbatasan kesempatan pendidikan dan pelatihan bagi kaum wanita untuk meningkatkan posisi tawar menuju kesetaraan gender.

- Masalah kesehatan dan hak reproduksi wanita yang kurang mendapat perlindungan dan pelayanan yang memadai.
- Keikut sertaan wanita dalam merumuskan dan mengambil keputusan dalam keluarga dan masyarakat amat terbatas.

- Keterbatasan akses terhadap media massa, sehingga cenderung media massa memakai tubuh wanita sebagai media promosi dan eksploitasi (dalam Durahim, 2001)

Secara lebih spesifik, Pudjiwati Sayogyo (1985) mengemukakan permasalahan yang dihadapi wanita di pedesaan:

- Tingkat pendidikan formal wanita di pedesaan lebih rendah dari laki-laki, sehingga jangkauan terhadap kesempatan kerja yang lebih baik dan keterampilannya pun menjadi lebih rendah.

- Kurangnya jangkauan terhadap pelayanan yang ada di desa, khususnya bagi wanita dari golonngan tidak mampu, menyebabkan pengaruh mereka relatif kecil dalam proses pengambilan keputusan dalam masyarakat. Artinya, banyak kepentingan dan kebutuhan wanita untuk kepentingan masyarakat yang terabaikan.

Bertolak dari berbagai permasalahan yang dihadapi wanita di tingkat internasional maupun nasional, maka inti permasalahannya adalah pendidikan. Ketidaksamaan kesempatan untuk memperoleh pendidikan formal dan nonformal antara pria dan wanita, khususnya di pedesaan, akan bermuara pada ketidakadilan dalam banyak aspek kehidupan wanita. Profil Wanita 2000 dari BPS menunjukkan bahwa wanita yang tidak pernah sekolah dan hanya tingkat SD, lebih besar persentasenya dari pria. Kesenjangan pendidikan semakin membesar seiring dengan tingginya jenjang pendidikan yang ditamatkan.

Rendahnya pendidikan formal wanita, menyebabkan skill-nya pun rendah pula, sehingga akses ke kesempatan kerja yang lebih baik pun menjadi kecil. Terbukti bahwa wanita yang bergerak di sektor domestik sebesar 55\%, dibanding pria hanya $0.97 \%$ (Profil Wanita 2000,BPS).

Selanjutnya, Supiandi (2001) menyatakan bahwa terpaan media massa pria lebih besar dari wanita. Padahal, informasi itu merupakan 
komoditas, sehingga orang yang memiliki informasi akan memiliki kekuatan dan kekuasaan. Maka, bila ibu-ibu rumah tangga yang terpaan informasinya tinggi, akan well inform, sehingga akan mendorong mereka ke posisi tawar yang lebih tinggi dalam proses pengambilan keputusan.

\section{Kerangka Teoretis dan Konseptual}

Mengacu pada teori komunikasi pembangunan Lerner, yang asumsi dasarnya apabila suatu daerah terbuka dari isolasi geografis melalui pembangunan jalan raya, maka akan berlangsung perubahan sosial melalui empat tahap yang saling berinteraksi. Terbukanya isolasi akan memicu urbanisasi, yaitu migrasi penduduk pedesaan ke daerah kota dengan tujuan untuk mewujudkan hasrat hidup baru. Urbanisasi akan mendorong literasi, sebab secara umum fungsi dasar melek huruf untuk menekan pemborosan tenaga dan untuk memudahkan melatih tenaga kerja dalam pengembangan industri yang dapat meningkatkan pertumbuhan nasional.

Selain itu, kemampuan baca tulis merupakan keahlian dasar bagi pengembangan sistem media. Hanya orang melek huruf yang mampu memproduk dan mengonsumsi isi media. Dengan demikian, literasi akan mempengaruhi partisipasi media massa.

Lebih lanjut peningkatan partisipasi media cenderung meningkatkan partisipasi di semua lini dari sistem kemasyarakatan. Penggunaan media mempercepat penyebaran empati, sekaligus menyebarkan tuntutan hidup modern. Hal ini mendorong lembaga lembaga partisipasi terkait memberi respons terutama di sektor ekonomi dan sosial. Penelitian Lerner (1978) di bidang ekonomi, mengungkapkan adanya korelasi signifikan antara tingkat literasi dan terpaan media massa dengan pendapatan dan dan industrialisasi. Juga di sektor politik, ditemukan korelasi signifikan antara tingkat literasi dan terpaan media massa dengan penggunaan hak politik.

Keempat variabel pada level teoretis, tingkat urbanisasi, tingkat literasi, terpaan media massa dan partisipasi pembangunan di break down ke level konsepsual menjadi aktivitas mobilitas, kesempatan pendidikan yang diraih, terpaan informasi dan pengambilan keputusan dalam pemeliharaan kesehatan reproduksi.

Mobilitas penduduk akan lancar bila ditunjang jalan raya dan alat-alat transportasi. Pool (dalam Weiner, 1966) menegaskan, tidak ada yang lebih revolusioner selain jalan raya, dalam memicu mobilitas penduduk. Mobilitas penduduk ke kota atau ke pasar akan menghasilkan pengetahuan dan pengalaman baru dari yang dilihat dan didengarnya. Diperolehnya informasi dan pengalaman baru ini menunjukkan berlangsungnya proses mobilitas psikis. Artinya, dari mobilitas fisik berlanjut ke mobilitas psikis.

Pendidikan merupakan break down dari konsep literasi pada level teoretis. Merujuk pada 12 Isu Keprihatinan Beijing dan masalah yang dihadapi wanita di pedesaan (Pudjiwati, 1985), masalah pokok wanita adalah pendidikan. Weiner (dalam Abraham, 1991) mengemukakan, makin efektif pendidikan, makim meluas perubahan yang dihasilkan.

Terpaan informasi, analog dengan pendapat Rosengren (1974) tentang terpaan media massa, adalah penggunaan informasi untuk memenuhi kebutuhan, sehingga diperoleh kepuasan. Indikator-indikatornya: (1) sumber-sumber informasi yang digunakan; (2) intensitas penggunaan waktu untuk tiap sumber informasi yang dirujuk; (3) jenis informasi yang dikonsumsi; dan (4) hubungan pengguna informasi dengan sumber atau informasi itu sendiri.

Pengambilan keputusan untuk pemeliharaan kesehatan reproduksi dalam konteks penelitian ini merupakan pengambilan keputusan yang berlangsung dalam keluarga. Merujuk pada Galvin dan Brommer (1982) yang disebut sebagai system of family decision making, yang dibangun oleh empat aspek: tipe-tipe pembuatan keputusan kebiasaaan yang berlaku dalam keluarga - langkahlangkah yang ditempuh dalam pembuatan keputusan - dan faktor-faktor yang mempengaruhi pembuatan keputusan.

Kesehatan reproduksi merupakan isu-isu yang kontroversial, sehingga penting dan aktual untuk dikaji dengan beberapa pertimbangan: (1) kesehatan reproduksi merupakan bagian hak asasi manusia yang bersifat universal yang harus 
dihargai dan dilindungi berbagai fihak; (2) kesehatan reproduksi berfungsi dalam pembentukan dan pengembangan generasi masa depan yang tangguh sebab kesehatan reproduksi merupakan dasar dan awal proses pengembangan yang akan menentukan kualitas SDM; (3) hak dan kesehatan reproduksi memiliki fungsi strategis dalam pembangunan wanita.

\section{Metodologi}

Penelitian ini menggunakan metode survei eksplanatoris. Melalui metode ini diharapkan dapat menjelaskan perbedaan-perbedaan yang terjadi dilihat dari karakteristik daerah penelitian dan karakteristik keempat kelompok responden pada keempat tahapan proses perubahan sosial yang terjadi akibat dibangunnya jalan raya yang membuka tabir isolasi fisik.

Sasaran penelitian adalah ibu-ibu rumah tangga yang telah menikah dan telah mempunyai anak. Bertolak dari selesainya pembangunan jalan raya (1978), ibu-ibu diklasifikasikan ke dalam kelompok yang menikah sebelum dan sesudah jalan raya dibangun.

Sampel responden untuk tiap kelompok diambil dengan teknik simple random sampling. Ukuran sampel sebesar 180 dialokasikan secara proporsional di ketiga kecamatan, sehingga setiap kecamatan ada 60 sampel yang dibagi menjadi empat kelompok.

Uji validitas instrumen meliputi validitas isi dan validitas konstruk dilakukan terhadap 40 orang responden, dengan menggunakam rumus korelasi Product Moment Pearson. Untuk mengetahui keterandalan instrumen lainnya dilakukan uji reliabilitas yang dilakukan dengan teknik belah dua/ half split method.

Sementara itu, uji hipotesis dilakukan dengan uji beda, yang bermaksud untuk mendeskripsikan perbedaan dari berbagai variabel utama penelitian dilihat dari karakteristik masing-masing kelompok penelitian dan dari karakteristik daerah penelitian. Uji signifikan ini dilakukan untuk sampel-sampel yang independen. Pengujian hipotesis uji beda dengan menggunakan analisis khi kuadrat.

\section{Hasil Penelitian}

Pengujian hipotesis memakai analisis khi kuadrat dengan kriteria terima $\mathrm{H}_{1}$ jika $\mathrm{x}^{2}$ hitung $>x^{2}$ tabel pada d.f $=(3-1)(3-1)$ dengan L.O.S 0.05= 9.488 .

Tabel 1. Hasil uji beda Aktivitas Mobilitas, Kesempatan Pendidikan, Terpaan Informasi dan Pengambilan Keputusan di Tiga Daerah Penelitian

\begin{tabular}{|c|c|c|c|c|}
\hline No & Variabel Penelitian & $X^{2}$ hitung & $X^{2}$ tabel & Kesimpulan statistik \\
\hline 1. & Aktivitas mobilitas & 28.7326 & 9.488 & $\begin{array}{l}\text { A) Ada perbedaan signifikan dalam } \\
\text { aktivitas mobilitas ibu-ibu di } \\
\text { Cibaliung, Panimbang dan Sumur }\end{array}$ \\
\hline 2. & $\begin{array}{l}\text { Kesempatan pendidikan } \\
\text { yang diraih }\end{array}$ & 7.4373 & 9.488 & $\begin{array}{l}\text { (A) Tidak ada perbedaan signifikan dalam } \\
\text { kesempatan pendidikan ibu-ibu di } \\
\text { ketiga daerah penelitian }\end{array}$ \\
\hline 3. & Terpaan informasi & 28.7326 & 9.488 & $\begin{array}{l}\text { A) Ada perbedaan signifikan dalam } \\
\text { terpaan informasi ibu-ibu di ketiga } \\
\text { daerah penelitian }\end{array}$ \\
\hline 4. & $\begin{array}{l}\text { Pengambilan keputusan } \\
\text { dalam pemeliharaan } \\
\text { kesehatan reproduksi }\end{array}$ & 4.6113 & 9.488 & $\begin{array}{l}\text { Tidak ada perbedaan signifikan dalam } \\
\text { pengambilan keputusan untuk } \\
\text { pemeliharaan kesehatan reproduksi di } \\
\text { ketiga daerah penelitian }\end{array}$ \\
\hline
\end{tabular}


Tabel 2. Uji Beda Aktivitas Moblilitas Keempat Kelompok Responden di Ketiga Daerah Penelitian

\begin{tabular}{|c|c|c|c|c|}
\hline No. & Daerah Penelitian & $X^{2}$ hitung & $\mathrm{X}^{2}$ tabel & Kesimpulan \\
\hline 1. & Cibaliung & 7.5838 & 12.392 & $\begin{array}{l}\text { Tidak ada perbedaan siginifikan } \\
\text { dalam aktivitas mobilitas pada } \\
\text { keempat kelompok ibu-ibu di } \\
\text { daerah Cibaliung }\end{array}$ \\
\hline 2. & Panimbang & 24.4 & 12.392 & $\begin{array}{l}\text { Ada perbedaan signifikan dalam } \\
\text { aktivitas mobilitas pada keempat } \\
\text { kelompok ibu-ibu di Panimbang }\end{array}$ \\
\hline 3. & Sumur & 9.1277 & 12.392 & $\begin{array}{l}\text { Tidak ada perbedaan siginifikan } \\
\text { dalam aktivitas pada keempat } \\
\text { kelompok ibu-ibu di daerah Sumur }\end{array}$ \\
\hline
\end{tabular}

Keterangan: d.f $=(4-1)(3-1)$ dengan L.O.S $0.05=12.392$ maka bila $\mathrm{x}^{2}$ hitung $>\mathrm{x}^{2}$ tabel, $\mathrm{H}_{1}$ diterima

\section{Tabel 3. Uji Beda Kesempatan Pendidikan Keempat Kelompok}

\section{Responden di Ketiga Daerah Penelitian}

\begin{tabular}{|c|c|c|c|c|}
\hline No. & Daerah Penelitian & $\mathrm{X}^{2}$ hitung & $X^{2}$ tabel & Kesimpulan \\
\hline 1. & Cibaliung & 6.7965 & 12.392 & $\begin{array}{l}\text { Tidak ada perbedaan signifikan } \\
\text { dalam kesempatan pendidikan pada } \\
\text { keempat kelompok ibu-ibu di } \\
\text { Cibaliung }\end{array}$ \\
\hline 2. & Panimbang & 31.8 & 12.392 & $\begin{array}{l}\text { Ada perbedaan signifikan dalam } \\
\text { kesempatan pendidikan pada } \\
\text { keempat kelompok ibu-ibu di } \\
\text { Panimbang }\end{array}$ \\
\hline 3. & Sumur & 6.6578 & 12.392 & $\begin{array}{l}\text { Tidak ada perbedaan signifikan } \\
\text { dalam kesempatan pendidikan pada } \\
\text { keempat kelompok ibu-ibu di Sumur }\end{array}$ \\
\hline
\end{tabular}


Tabel 4. Uji Beda Terpaan Informasi Keempat Kelompok Responden di Ketiga Daerah Penelitian

\begin{tabular}{|c|c|c|c|c|}
\hline No. & Daerah Penelitian & $X^{2}$ hitung & $\mathrm{X}^{2}$ tabel & Kesimpulan \\
\hline 1. & Cibaliung & 16.4968 & 12.392 & $\begin{array}{l}\text { A) Ada perbedaan signifikan dalam } \\
\text { terpaan informasi pada keempat } \\
\text { kelompok ibu-ibu di Cibaliung }\end{array}$ \\
\hline 2. & Panimbang & 28.3523 & 12.392 & $\begin{array}{l}\text { Ada perbedaan signifikan dalam } \\
\text { terpaan informasi pada keempat } \\
\text { kelompok ibu-ibu di Panimbang }\end{array}$ \\
\hline 3. & Sumur & 3.0545 & 12.392 & $\begin{array}{l}\text { Tidak ada perbedaan signifikan } \\
\text { dalam terpaan informasi pada } \\
\text { keempat kelompok ibu-ibu di Sumur }\end{array}$ \\
\hline
\end{tabular}

Tabel 5. Uji Beda Pengambilan Keputusan Pemeliharaan Kesehatan Reproduksi Keempat Kelompok Responden di Ketiga Daerah Penelitian

\begin{tabular}{|c|c|c|c|c|}
\hline No. & Daerah Penelitian & $\mathrm{X}^{2}$ hitung & $X^{2}$ tabel & Kesimpulan \\
\hline 1. & Cibaliung & 4.1860 & 12.392 & $\begin{array}{l}\text { A) Tidak ada perbedaan signifikan } \\
\text { dalam pengambilan keputusan } \\
\text { pada keempat kelompok ibu-ibu } \\
\text { di Cibaliung }\end{array}$ \\
\hline 2. & Panimbang & 0.1538 & 12.392 & $\begin{array}{l}\text { Tidak ada perbedaan signifikan } \\
\text { dalam pengambilan keputusan } \\
\text { pada keempat kelompok ibu-ibu } \\
\text { di Panimbang }\end{array}$ \\
\hline 3. & Sumur & 7.5 & 12.392 & $\begin{array}{l}\text { Tidak ada perbedaan signifikan } \\
\text { dalam pengambilan keputusan } \\
\text { pada keempat kelompok ibu-ibu } \\
\text { di Sumur }\end{array}$ \\
\hline
\end{tabular}

Hasil uji hipotesis disajikan dalam 5 tabel yang terdiri dari tabel 1 mendeskripsikan hasil uji beda keempat variabel. Selanjutnya tabel 2 sampai tabel 5 menggambarkan hasil uji beda yang keempat variabel pada masing-masing daerah penelitian.

\section{Pembahasan}

\subsection{Perbedaan Aktivitas Mobilitas}

Adanya perbedaan signifikan aktivitas mobilitas ibu-ibu rumah tangga di ketiga daerah penelitian, terutama terjadi di daerah yang paling 
dekat ke kota relatif besar, dibandingkan dengan dua daerah lain yang lebih jauh. Begitu pula untuk uji beda variabel yang sama untuk keempat kelompok ibu-ibu, hanya daerah yang paling dekat ke kota yang menunjukkan adanya perbedaan signifikan. Mobilitas yang tinggi pada ibu-ibu di daerah itu menjadi logis, sebab jarak ke kota besar cukup dekat, kurang lebih $15 \mathrm{~km}$, ditunjang sarana transportasi yang memadai dengan biaya transport yang murah/terjangkau. Kondisi ini meningkatkan motif ekonomi untuk berdagang di kota. Sementara, faktor ekonomilah yang merupakan faktor determinan dalam memicu penduduk untuk bermobilitas (Lee, 1966; Todaro, 1978; dan Titus, 1982).

Selain itu Rhoda (1979) dan Lipton (1980) berpendapat, penduduk daerah yang dekat perkotaan apalagi yang sudah terintegrasi dengan kota dan didukung fasilitas yang memudahkan untuk ke kota, maka kecenderungan untuk bermobilitas tinggi. Artinya, selain motif ekonomi kondisi seperti itu akan merangsang ibu-ibu untuk bermobilitas, terutama mobilitas commuting guna kepentingan-kepentingan lainnya.

Sementara itu, untuk daerah yang terjauh ke kota, dan secara administratif baru dikembangkan menjadi kecamatan, maka derap pembangunannya pun belum seberhasil kedua kecamatan lainnya. Ibu-ibu umumnya hanya ibu-ibu rumah tangga yang tidak punya penghasilan sendiri. Sebagian kecil menjadi pedagang atau buruh pengrajin ikan asin. Ibu-ibu yang berprofesi sebagai pegawai, umumnya berasal dari pendatang. Aktivitas mobilitasnya pun hanya di seputar desanya, kalaupun ada yang pedagang, urusan untuk membeli barang dagangan ke kota umumnya menjadi tugas para suami.

Teori Lerner yang menyatakan terbukanya isolasi fisik akan mendorong mobilitas (tepatnya urbanisasi) penduduk, tidak teruji secara utuh. Hanya ibu-ibu rumah tangga yang tinggal di daerah dekat kota yang memiliki mobilitas tinggi (commuting), mereka yang tinggal di daerah yang jauh ke kota sebaliknya. Mobilitas mereka hanya di seputar desa dan pada kelompok ibu-ibu yang berprofesi sebagai pedagang pun tugas untuk berbelanja barang dagangan ke luar kota menjadi tugas suaminya. Fenomena ini menunjukkan adanya bias gender yang menempatkan kaum perempuan berada di wilayah domestik.

\subsection{Perbedaan Kesempatan Pendidikan yang Diraih}

Pengujian hipotesis menunjukkan, tidak ada perbedaan dalam kesempatan pendidikan yang diraih ibu-ibu rumah tangga di ketiga daerah penelitian, 55\% mereka hanya sempat mengecap bangku SD. Berdasarkan keempat pengelompokan, ibu-ibu pun sama tidak ada perbedaan signifikan di bidang pendidikan. Fenomena ini sebagai dampak dari keterisolasian geografis, yang menghambat dinamika pembangunan termasuk di bidang pendidikan. Sebagaimana diketahui, ibuibu responden ini sebagai produk pendidikan di masa daerahnya masih tertutup, sehingga sekolahsekolah jauh dan mahal. Padahal, di mata Abraham (1991), melalui pendidikan, mata masyarakat akan terbuka wawasannya tentang dunia baru. Selain itu, akan mencerdaskan mereka, sehingga mudah menciptakan alternatif-alternatif untuk menyiasati tradisi-tradisi yang menghambat kemajuan. Tradisi yang berkembang di masyarakat di bidang pendidikan, umumnya para orang tua lebih mendahulukan pendidikan anak laki-laki dari pada anak perempuan. Alasan yang diajukan, sebab anak laki-laki akan memikul tanggung jawab keluarganya. Di tengah iklim tradisi masyarakat yang seperti itu, tidak heran apabila pendidikan ibu-ibu rumah tangga umumnya hanya SD. Tradisi inipun tumbuh sebagai produk konstruksi gender, yang meminggirkan hak-hak perempuan di bidang pendidikan. Pendidikan mereka yang rendah, menjauhkan mereka dari akses ke bidang produktif, sehingga menghambat mobilitas mereka ke perkotaan.

Penemuan penelitian ini pun turut menggoyahkan teori Lerner bahwa mobilitas akan meningkatkan pendidikan. Pendidikan yang efektif akan memperluas perubahan yang dihasilkan (Abraham, 1991). Termasuk aktif bermobilitas, karena pendidikan yang baik akan membuka akses 
ke kesempatan kerja yang lebih baik yang akan mendorong untuk aktif pula bermobilitas. Amat sulit untuk meningkatkan kembali pendidikan formal mereka ke jenjang yang lebih tinggi. Inkeles dan Smith (1974) mengemukakan bahwa pendidikan untuk memajukan manusia bukan hanya melalui sekolah formal semata, banyak institusi lain yang berfungsi di bidang pendidikan seperti media massa, tempat kerja, organisasi, dan sebagainya.

\subsection{Perbedaan Terpaan Informasi}

Perbedaan terpaan informasi ibu-ibu di ketiga daerah penelitian, teruji secara signifikan. Begitu terpaan informasi atas empat pengelompokan ibuibu teruji, ada perbedaan signifikan untuk daerah yang dekat ke kota. Hanya daerah yang jauh ke kota menunjukkan tidak ada perbedaan terpaan informasi untuk keempat kelompok ibu-ibu rumah tangga.

Sumber informasi kesehatan reproduksi yang digunakan bisa dari sumber persona maupun media. Seseorang menggunakan atau mencari informasi, didorong oleh motif curiosity want. Munculnya kebutuhan informasi, antara lain, karena adanya kesenjangan pengetahuan pada seseorang untuk mengantisipasi kejadian yang dihadapinya, sehingga menimbulkan disharmoni perasaan. Untuk menyamankan kembali kondisi psikisnya, ia akan mencari informasi yang dapat memenuhi kebutuhannya (Cognitive dissonance theory).

Ditinjau dari sisi pandang komunikasi pembangunan, terpaan media/informasi berkaitan dengan pendidikan. Pembangunan pendidikan yang berhasil, akan menimbulkan industri media. Sebaliknya, media akan meningkatkan kecerdasan khalayaknya (Lerner, 1958).

\subsection{Perbedaan Pengambilan Keputusan dalam Pemeliharaan Kesehatan Reproduksi}

Secara statistik telah teruji bahwa tidak ada perbedaan signifikan dalam pengambilan keputusan untuk pemeliharaan kesehatan reproduksi, baik antara ketiga daerah penelitian maupun keempat kelompok ibu-ibu. Secara selintas, fenomena ini tampak tidak selaras dengan budaya patriarkhat, yang kental meronai kehidupan masyarakat, di mana suami dominan memegang tongkat komando pengambilan keputusan dalam rumah tangganya.

Dikaitkan dengan kebijakan pemerintah mengenai KIE-KB, yang selama ini gencar dilakukan dengan target sasaran yang umumnya ibu-ibu rumah tangga. Hasil kebijakan ini memunculkan kesenjangan pengetahuan kesehatan reproduksi antara suami dan istri. Ditambah lagi adanya kecenderungan pada para suami yang tidak termotivasi kuat untuk mencari informasi dari sumber lain. Tidak heran bila para suami tidak well inform dengan pengetahuan kesehatan reproduksi.

Kondisi tersebut mendorong para suami menjadi lebih akomodatif dalam proses pengambilan keputusan. Mereka meminta informasi dari istrinya dan menanyakan apa yang diinginkannya, sehingga seperti dikatakan Turner (1990) pengambilan keputusan akomodatif menuntut banyak take and give dari yang terlibat diskusi. Dengan demikian kesenjangan informasi tadi, memberikan kontribusi positif pada peningkatan daya tawar ibu-ibu rumah tangga dalam proses pengambilan keputusan. Ironisnya, peningkatan bargaining position ibu-ibu rumah tangga dalam pengambilan keputusan pemeliharaan kesehatan reproduksi bukan dilandasi prinsip kesetaraan gender dari para suami, tapi disebabkan para suami umumnya kurang well inform sehingga mereka memberi keleluasaan pada istrinya untuk mengambil keputusan.

\section{Kesimpulan}

(1) Terbukanya isolasi fisik, umumnya tidak mendorong ibu-ibu rumah tangga bermobilitas ke daerah perkotaan untuk kegiatan ekonomi, bidang ini cenderung didominasi oleh para suami. Fenomena ini memperkuat bias gender yang memosisikan wanita pada kegiatan domestik dan laki-laki di sektor publik.

(2) Pendidikan ibu-ibu rumah tangga pada 
umumnya SD tamat dan tidak tamat. Rendahnya pendidikan mereka selain sekolah relatif sulit/mahal karena keterisolasian geografis, diperparah oleh kontruksi gender yang mendahulukan anak laki-laki untuk melanjutkan sekolah dari pada anak perempuan. Alasannya, anak perempuan akhirnya akan masuk dapur, sementara anak laki-laki harus memikul tanggung jawab keluarga.

(3) Terpaan informasi kesehatan reproduksi para ibu-ibu rumah tangga umumnya cukup. Fenomena ini terjadi akibat intensifnya kegiatan penyuluhan/KIE-KB - Kesehatan dengan sasaran utama ibu-ibu rumah tangga. Sementara KIE-KB - Kesehatan untuk kaum bapak relatif kurang.

(4) Pengambilan keputusan untuk pemeliharaan kesehatan reproduksi umumnya dilakukan oleh ibu-ibu rumah tangga. Fenomena ini bukan menunjukkan adanya pengakuan suami atas adanya kesamaan hak antara suami dan istri dalam pengambilan keputusan untuk semua urusan dalam rumah tangga. Penyerahan wewenang pengambilan keputusan kepada ibu-ibu rumah tangga, karena suami umumnya tidak well informed tentang kesehatan reproduksi, sementara mereka khawatir bila terjadi sesuatu pada istrinya.

\section{Daftar Pusaka}

Abraham, Francis M. terjemahan M. Rusli Karini. 1991. Modernisasi di Dunia Ketiga: Suatu Teori Umum Pembangunan. Yogyakarta: Tiara Wacana.

Agus Dwiyanto dan Muhadjir Darwin. (ed) 1996. Seksualitas, Kesehatan Reproduksi dan Ketimpangan Gender. Jakarta: Pustaka Sinar Harapan.
Baumhouer. 1995. "From the 1985 World Conference on Women in Beijing. ” Dalam BATU Research and Documentation Center Journal. Volume IV no 2. 1995. Manila. Philippines.

Galvin, Kathleen M. and Bernard J. Brommel. 1982. Family Communication: Cohesion and Change Gleview. Illionis: Scott, Foresman and Company.

Ida Bagoes Mantra. 1999. Mobilitas Penduduk Sekuler dari Desa ke Kota di Indonesia. Yogyakarta: Pusat Penelitian dan Studi Kependudukan Universitas Gajah Mada.

Inkeles, Alex. 1981. "Making Man Modern: On The Causes and Consequences of Individual Change in Six Developing Countries." American Journal of Sociology - 75.

Lerner, Daniel. 1978. Memudarnya Masyarakat Tradisional. Muljarto Tjokrowinoto (Ed). Yogyakarta: Gajah Mada University Press.

Lorber, Yudith. 2000. Using Gender to Undo Gender.Feminist Theory. Volume 1. London: Sage Publications.

Pudjiwati Sajogyo. 1985. Peranan Wanita dalam Perkembangan Masyarakat Desa. Jakarta: Rajawali.

Rosengren, Karl Erik. 1974. "Uses and Stratification A Paradigm Outlined." Dalam Blumler, Jay G. and Elihn Kotz (Editors). The Uses of Mass Communication: Current Perspectives on Stratifications Research. London: Sage Publications. Beverly Hills.

So, Alvin Y. 1990. Social Change and Development: Modernization, Dependency and World System Theories. Sage Library of Social Reseach 178. Newbury Park. London. New Delhi: Sage Publications. 
